DOI: 10.12731/2658-6649-2019-11-5-128-133

УДК 616.995.1(057.56)

\title{
ГЕЛЬМИНТОЗЫ РЕСПУБЛИКИ КРЫМ
}

Радковский В.А., Жукова А.А., Смирнова С.Н.

На территории России самыми распространенными гельминтозами являются энтеробиоз и аскаридоз, которые также являются самыми распространенными на территории Республики Крым. Наибольшее количество случаев заражения данными гельминтозами приходится на детское население Крыма. Случаи заражения другими гельминтозами на территории Крыма спорадичныл.

Ключевые слова: гельминты; гельминтозы; энтеробиоз; аскаридоз.

\section{HELMINTHOSIS IN THE CRIMEAN REPUBLIC}

\author{
Radkovskij V.A., Zhukova A.A., Smirnova S.N.
}

In Russia, the most common helminthosis are enterobiosis and ascariasis, which are also the most common in the Republic of Crimea. The largest number of cases of infection with these helminthosis are among on the children's population of the Crimea. Infections other helminthosis in the Crimea sporadically.

Keywords: helminthes; helminthosis; enterobiosis; ascariasis.

\section{Введение}

В России регистрируется 70 видов гельминтов, распространенность имеют 30 видов, из них пятая часть - 12 видов подлежат официальной регистрации и подвергаются подсчету и анализу. Гельминтозы - заболевания человека, вызываемые паразитическими червями, составляют $86,2 \%$ от всех паразитарных заболеваний на территории Российской Федерации [1, c. 160]. В зависимости от пропагативных стадий выделяют три основных типа гельминтозов. Биогельминтозы - заболевания, вызванные паразитическими червями, в жизненном цикле которых присутствует промежуточный хозяин (человек или животное). При геогельминтозах у возбудителя отсутствует промежуточный хозяин, а при контагиозных гельминтозах предварительное развитие организма во внешней среде отсутствует, ввиду того, что из тела хозяина они выходят изначально способными к инвазии. 
Самым распространенным гельминтозом в Российской Федерации является энтеробиоз, на него приходится 71,5\% от всех случаев паразитарных инвазий. Около 97,5\% случаев энтеробиоза приходится на возраст населения до 17 лет. Аскаридоз занимает второе место на территории России по распространенности (85-90 случаев на 100 тыс. населения), причем 70\% случаев заражения приходится на детское население. Случаи заражения другими паразитическими червями отмечаются гораздо реже в связи со сложными жизненными циклами и специфическими условиями развития паразитов [1, с. 160,2 , с. 10, 3, с. 13]. В связи с этим, целью работы явилось исследование частоты заболеваемостью различными гельминтозами человека в Республике Крым.

\section{Материалы и методы исследования}

В работе использовались статистические данные, предоставленные Межрегиональным управлением Роспотребнадзора по Республике Крым и г. Севастополю, была использована информация из государственных докладов «О состоянии санитарно-эпидемиологического благополучия населения в Российской Федерации» Федеральной службы по надзору в сфере защиты прав потребителей и благополучия человека» за период с 2014 по 2017 гг. [1].

\section{Результаты исследования}

В течение этого времени в Крыму было зарегистрировано 11 видов гельминтозов человека. Количество выявленных заболеваний за 4 года составило 7530, в том числе, за 2014 г. - 2731, за 2015 г. - 1848, за 2016 г. 1843, за 2017 г. - 1108. Таким образом, в динамике была отмечена тенденция к снижению заболеваемости гельминтозами. Сравнительная характеристика, отображающая инвазированность населения на примере относительного показателя, демонстрирует, что к 2015 году заболеваемость снизилась на 32,9\% по сравнению с 2014 г., к 2016 г ситуация не изменилась относительно предыдущего, а к 2017г. наблюдалось уменьшение на $39,94 \%$ в сравнении с предыдущим годом. Таким образом, за весь период с 2014 по 2017 гг. снижение заболеваемости составило 59,9\%. Энтеробиоз, как контагиозный детский гельминтоз, является самым распространенным паразитарным заболеванием на территории Крыма. С 2014 по 2017 гг. уровень заражения составил 6993 случая, что составляет 92,87\% от общего числа паразитарных инвазий, в том числе: в 2014г. - 2582 случая, в 2015 г. - 1740, в 2016г. - 1697, и в 2017 - 974. Показатели заболеваемости 
населения энтеробиозом составили: в 2014г. 136,54 (148,72 в РФ); в 2015 $91,24(151,82)$; в 2016 - 88,76 (163,3); в 2017 - 50,89 (154,73). При этом наибольшее количество случаев заражения было отмечено в возрастной группе до 17 лет - 92,3\% или 6427 случаев заражения, с преобладанием случаев инвазии у детей 3-6 лет (2841 случай). Это обусловлено высокой контагиозностью данного паразита у детей в дошкольных и школьных учреждениях [4, с. 137]. Дети в возрасте до 1 года оказались менее подвержены заражению энтеробиозом, что подтверждалось количеством зараженных, всего 36 случаев. Инвазированность среди городского населения составила 4597 случаев, среди сельского - 2696 случаев. Данные показатели связаны с большей плотностью населения в городах и более высоким уровнем обследования городских жителей.

Аскаридоз - это геогельминтоз, при котором развитие яиц и личинок паразита происходит в почве. Заражение человека аскаридозом в основном происходит при употреблении немытых, обсемененных яйцами паразита овощей, фруктов, загрязненной воды, несоблюдении правил личной гигиены и т.д. В Крыму аскаридоз является вторым по частоте встречаемости гельминтозом, хотя при этом его показатель невысок. В 2014 г. он составил 7,03 на 100 тыс.; в 2015 г. - 4,77; в $2016-6,85$ и в 2017 г. - 5,9. Дети оказались подвержены инвазии в среднем в 15-20 раз чаще, чем взрослое население. Частота выявляемости аскаридоза среди городского населения выше по отношению к сельским жителям. Она составила в 2014 г. 5,8 на 100тыс.; в 2015 г. - 6,1; в 2016 г. - 10,1; в 2017 г. - 8,9. Среди сельского населения, соответственно: 8,$3 ; 3,4 ; 10,1 ; 2,8$. Случаи заражения другими геогельминтозами в Крыму спорадичны: 5 случаев токсокароза (4, из которых в сельской местности), трихоцефалез - 1 случай.

За исследованный период было выявлено 22 случая дирофиляриоза, которым дирофиляриозом происходило при укусе комарами. Окончательными хозяевами паразита являются в основном собаки, реже кошки. Значительное количество случаев заражения данным гельминтом связано с высокой численностью бездомных животных, отсутствием мероприятий по выявлению и дегельминтизации зараженных бездомных и домашних собак и кошек [5, с. 147].

Случаи заражения, вызываемые паразитическими плоскими червями, спорадичны, нерегулярны и не имеют значительного эпидемиологического значения. Так за изученный период были зафиксированы: гименолепидоз 5 случаев, тениаринхоз - 1 случай, тениоз - 3 случая, дифиллоботриоз - 6 случаев, эхинококкоз - 25 случаев (из которых 13 случаев в 2017). Незна- 
чительное количество случаев инвазии плоскими червями обусловлены сложными жизненными циклами этих гельминтов.

\section{Заключение}

Из 11 регистрируемых в Республике Крым нозологических форм гельминтозов, 9 являются фактически единично встречаемыми, их частота не превышает 1 случая на 100 тыс. человек. Заболеваемость самым распространенным гельминтозом - энтеробиозом имеет устойчивую тенденцию к снижению, в среднем на 1,5-2\% в год, второй по численности аскаридоз в целом остается на одинаковом уровне. Было отмечено лидирование городского населения в территориальной структуре заболеваемости: гельминтозы среди городских жителей регистрировались на 47,5\% чаще, чем среди сельского населения.

Информация о конфликте интересов. Авторы заявляют об отсутствии конфликта интересов.

Информация о спонсорстве. Исследование не имело спонсорской поддержки.

\section{Список литературы}

1. О состоянии санитарно-эпидемиологического благополучия населения в Российской Федерации в 2017 году: Государственный доклад. М.: Федеральная служба по надзору в сфере защиты прав потребителей и благополучия человека, 2018. 268 с.

2. Анализ заболеваемости наиболее распространенными паразитозами в Республике Башкортостан / Кайданек Т.В., Мухаметзянов А.М., Асылгареева Г.М. и др. // Медицинский вестник Башкортостана. 2015. Т.10. №1. С. 10-14.

3. Кузнецов Н.И. Гельминтозы // Российский семейный врач. 2010. Т. 14. №4. C. 13-23.

4. Клинические и лабораторные аспекты энтеробиоза / Головченко Н.В, Ширинян А.А., Костенич О.Б., Теличева В.О. // Теория и практика паразитарных болезней животных. 2016. С. 137-139.

5. Дирофиляриоз служебных собак в Астраханской области / Аракельян Р.С., Чернухин Д.А., Галимзянов Х.М., Карпенко С.Ф. и др. // Российский паразитологический журнал. 2017. Т. 40. № 2 . С. 146-149.

\section{References}

1. O sostoyanii sanitarno-epidemiologicheskogo blagopoluchiya naseleniya v Rossijskoj Federacii v 2017 godu: Gosudarstvennyj doklad. M.: Feder- 
al'naya sluzhba po nadzoru $\mathrm{v}$ sfere zashchity prav potrebitelej i blagopoluchiya cheloveka [The state of sanitary and epidemiological welfare of the population in the Russian Federation in 2017: State report. Moscow: Federal service for supervision of consumer rights protection and human welfare]. 2018. 268 p.

2. Analysis of the incidence of the most common parasites in the Republic of Bashkortostan [Insedence of the most common parasitosis in the Repablic of Bashcortostan] / Kaydanek T.V., Mykhametzjanov A.M., Asylgareeva G.M. // Vestnik BGMU, 2015, № 1, pp. 10-14.

3. Kuznetsov N.I. / Gel'mintozy [Helmithiasis] // Rossijskij semejnyj vrach, 2010, № 4, pp. 13-23.

4. Klinicheskie i laboratornye aspekty enterobioza [Clinical and laboratory aspects of Enterobius vermicularis infection] / Golovchenko N.V., Shirinyan A.A., Kostenich O.B., Telicheva V.O. // Teoriya i praktika parazitarnyh boleznej zhivotnyh, 2016, pp. 137-139.

5. Dirofilyarioz sluzhebnyh sobak v Astrahanskoj oblasti [Dirofilariasis in tracking dogs from Astrakhan region] / Arakel'yan R.S., Chernuhin D.A., Galimzyanov H.M., Karpenko S.F. // Rossijskij parazitologicheskij zhurnal, 2017, V. 40, №. 2, pp. 146-149.

\section{ДАННЫЕ ОБ АВТОРАХ}

Радковский Владислав Алексеевич, студент 1 курса І-го медицинского факультета

Медицинская академия имени С.И. Георгиевского (структурное подразделение) ФГАОУ ВО «Крымский федеральный университет им. В.И. Вернадского»

бульвар Ленина, 5/7, г. Симферополь, Республика Крым, 295051, Российская Федерачия

VladRadkovskij@gmail.com

Жукова Анна Александровна, кандидат биологических наук, доцент кафедры биологии медицинской

Медииинская академия имени С.И. Георгиевского (структурное подразделение) ФГАОУ ВО «Крымский федеральный университет им. В.И. Вернадского»

бульвар Ленина, 5/7, г. Симферополь, Республика Крым, 295051, Российская Федераиия anna_crimea09@mail.ru 
Смирнова Светлана Николаевна, кандидат биологических наук, доцент кафедры биологии медицинской

Медицинская академия имени С.И. Георгиевского (структурное подразделение) ФГАОУ ВО «Крымский федеральный университет им. В.И. Вернадского»

бульвар Ленина, 5/7, г. Симферополь, Республика Крым, 295051, Российская Федерация

bioligkrim@mail.ru

\section{DATA ABOUT THE AUTHORS}

Radkovskij Vladislav Alekseevich, student of 1-st course of 1-st Medical Faculty Medical Academy named after S.I. Georgievsky in the Federal state autonomous educational institution of higher education "Crimean Federal University named after V.I. Vernadsky»

5/7, Lenin Avenue, Simferopol, Republic of Crimea, 295051, Russian Federation

VladRadkovskij@gmail.com

Zhukova Anna Alexandrovna, $\mathrm{PhD}$ of the Department of medical biology Medical Academy named after S.I. Georgievsky in the Federal state autonomous educational institution of higher education "Crimean Federal University named after V.I. Vernadsky»

5/7, Lenin Avenue, Simferopol, Republic of Crimea, 295051, Russian Federation

anna_crimea09@mail.ru

ORCID: 0000-0002-0725-2089

Smirnova Svetlana Nicolaevna, $\mathrm{PhD}$ of the Department of medical biology Medical Academy named after S.I. Georgievsky in the Federal state autonomous educational institution of higher education «Crimean Federal University named after V.I. Vernadsky»

5/7, Lenin Avenue, Simferopol, Republic of Crimea, 295051, Russian Federation

bioligkrim@mail.ru

ORCID: 0000-0002-4460-0935 